\title{
Online Education as an Active Learning Environment in the New Normal
}

\author{
${ }^{1}$ Agripina F. Banayo, Ed.D \& ${ }^{2}$ Chris Jezrel B. Barleta, LPT
}

\begin{abstract}
This study examined the students' perception on the collaborative-constructivist learning experience in the online education of the Laguna State Polytechnic University (LSPU) during the 'new normal' learning modality due to COVID-19 pandemic. The study utilized the descriptive-survey research using the Online Learning Environment Survey (OLLES) questionnaire comprising the seven (7) components namely: student collaboration, computer competence, active learning, teacher support, information design and appeal, material environment, and reflective thinking and the Community of Inquiry (COI) survey on the online learning experiences on social, teaching, and cognitive presence. The data were gathered from the 106 fourth year students of the College of Teacher Education (CTE) through Google Form. The findings proved that the respondents have a favorable perception on their online learning environment in terms of collaboration, computer competence, active learning, teacher support, information design and appeal, material environment, and reflective thinking. The outcomes exhibited a positive perception of learners towards social presence, teaching presence, and cognitive presence in their learning experiences. The findings of the current investigation also pointed that there is a significant relationship between learners' online learning environment and their learning experiences in the new normal education. Through this, educators will be able to deliver a collaborative-constructivist learning experience among learners.
\end{abstract}

Keywords:

online education, active learning environment, collaborative-constructivist learning experience, community of inquiry, new normal

Suggested Citation: Banayo, A.F. \& Barleta, C.B. (2021). Online Education as an Active Learning Environment in the New Normal. International Journal of Educational Management and Development Studies, Volume 2, Issue 4, pp. 72 - 96.

About the authors:

${ }^{1}$ Corresponding Author. Associate Professor III, Laguna State Polytechnic University-San Pablo City Campus

${ }^{2}$ Part-time Instructor, Laguna State Polytechnic University-San Pablo City Campus 


\section{Introduction}

The CoViD-19 pandemic reconstructed education across the world. Educators are compelled to modify their teaching instruction from face-to-face education to online distance learning. However, not all educational institutions are proficient in conducting online learning well (Louis-Jean, \& Cenat, 2020). Accordingly, it has brought unprecedented challenges to schools and learners in the Philippines. As no one can predict when the pandemic will end, infections still escalate even though countries around the world are implementing plans and procedures to contain the virus. In the educational milieu, Tria (2020) suggests that this new normal be taken into account in the planning and implementation of the "new normal educational policy" to support and maintain quality education amidst community quarantine.

The issues, problems, and trends that are emerging in the present and will emerge in the future should be addressed using the lens of the new educational norm. Opportunities and challenges should be understood and approached as a crucial matter. It is challenging to a great extent, to impart and administer quality education amidst exceptional times. It is also a challenge to be equipped when another predicament happens in the future (Tria, 2020). Thus, the Commission on Higher Education (CHED) advised public and private higher education institutions (HEIs) to employ available e-learning, distance learning, and other alternative modes of delivery (CHED, 2020). Online teaching and learning materials are encouraged to be utilized including but not limited to Google Classroom, Zoom, YouTube, Ted Talk, Email, and social media.

At the height of the pandemic, some educational institutions were equipped to immediately shift to online distance learning. Hence, these academies were less disturbed by the pandemic. On the other hand, other educational institutions were caught unprepared due to lack of essential e-learning facilities. As the situation forced every learning institution to online learning, institutions also advanced the competencies to meet the demands both on the facilities and teaching and learning. While success of online learning depends on effective preparation and appropriate resources, educational technologies and digital equipment update is a must (Louis-Jean \& Cenat, 2020). With the pressures of online learning, educational 
levels and curricula areas employ networked computers, software applications, and computer simulations in learning activities. For example, web-based and online software applications such as browsers, search engines, communication tools, and databases are popularized as teachers utilize them for education (Clayton, 2007). Described as borderless teaching and learning process, online education needs to be just as efficient as face-to-face education. For this, Callo and Yazon (2020) propose that it gives more weight the learning experience, content quality, and learner engagement.

Diverse e-learning resources with numerous asynchronous and synchronous communication devices provide a meaningful, more interactive online learning environment enabling varieties of learning styles to be better supported (Bates, 2000; Haynes, 2002; Ladyshewsky, 2004b; Mann, 2000). The transition from a conventional face-to-face learning environment to an online learning environment devised, executed, analyzed, and improved new ways of teaching and learning. There has been a paradigm shift in the learning environment for both educators and learners. (Chang \& Fisher, 2001; Further Education Resources for Learning, 2007; Kent, O'Neil, \& Page, 2006; National Science Board, 2006). However, there is a possibility that students who do well in face-to-face classes will not succeed in online classes (Wood, 2005). It is well-experimented that an online learning environment can significantly affect the learning experiences of learners based on their attitudes and opinions (Clayton, 2007).

The LSPU adopted online learning or flexible learning for the safety of the educators and learners during the COVID-19 pandemic. It made the teaching-learning process feasible even there are no face-to-face interactions. This model allowed the teaching instruction be delivered using synchronous and asynchronous classes. In lieu of the transitions and challenges brought about by the pandemic, the University also provided extended assistance and further means of support to better serve its faculty and students. As such, this study aimed to assess the learning experiences of the students in the crisis-driven online learning environment. Specifically, it evaluated the student collaboration, computer competence, active learning, teacher support, information design and appeal, material environment, and reflective thinking. It also surveyed the online learning experiences on social, teaching, and cognitive presence. 


\section{Literature review}

\subsection{Active Online Learning Environment}

Online learning is simply learning that occurs over the internet. To Radford (1997), it pertains to materials obtainable through a computer using networks. An online learning environment is described by Chang and Fisher (1999) as a platform consisting of digitally created content resources and communication mechanisms to enable interplay. It is a formal instructional method in which the student and the teacher are not together and the internet is adopted to accommodate a connecting link among them (McKnight \& Edwards, 2007). In this environment, there is interaction of the students with the content, others learners, and their teacher with the use of the internet (Siragusa, 2005) as such there are internet-enabled instructional tools and web-based technologies to facilitate education (Dabbagh \& Bannan-Ritland, 2005). It may also be called e-learning, e-training, or web-based instruction. Clearly, there are different manners educationalists, at every level, use the web in delivering education (Clayton, 2007).

In designing an active online learning environment, there are many procedures, frameworks, and theories to consider. These serve as blueprints for educators in investigating, devising, executing, assessing, and enhancing instructional processes. The focus of these models may include but is not limited to student engagement, persistence, and performance. In creating an online learning environment favorable to a significant level of engagement, educators should utilize an instructional design framework and a set of strategies that highlight cooperation, collaboration, facilitation, and feedback strategies in online learning contexts (Czerkawski \& Lyman, 2016). Educators must rethink their purposes, how they will assist students, and the role of students being self-directed learners, engaged citizens, and independent social agents (Rapanta et al., 2021). The crisis-driven transition of the learning environment can be more effective, active, resilient, and significant through a harmonious synthesis of material and digital devices and designs.

In designing effective online learning environment, educators look into social, cognitive and teaching presence.

Social Presence. Social presence is essential in supporting an extensive, welcoming, and active learning environment (Cooper et al., 2020). Fostering social presence by promoting intercommunication between learners and between learners and the teacher will 
make the delivery of curricula in higher education effective. An online learning environment where learners can convey their feelings and communicate openly will make learners feel secure. To promote active online learning in terms of social presence, students should be allowed to post video replies or work on online applications like screen casting (Dunlap \& Lowenthal, 2018; Seckman, 2018).

Cognitive Presence. Cognitive presence assists learners in exercising critical thinking and intuition (Cooper et al., 2020). Given proper importance, cognitive presence can make students collaborate and engage in an essential conversation that offers higher-order learning. Eminent to cognitive presence was the necessity to devise curricula that include diverse student groups with different learning styles, adjustability, and cultural backgrounds. To support active online learning in terms of cognitive presence, learners can make and post materials, quest out and post sources (Dunlap \& Lowenthal, 2018).

Teaching Presence. The key to a successful teaching and learning process is greatly dependent on the teacher. In an online learning environment, there are numerous issues that teachers need to attend to. In terms of facilitation of discussion, teachers should guarantee that the students know other people's views who have a different cultural background. All students should be allowed to contribute to the learning process. It is the role of the teacher to shape an online learning environment that is safe and protected. Thus, in setting the mood, teachers need to evaluate the reality of the complicated and stressful environments students will encounter in the workplace with the secured and protected learning environment (Cooper et al., 2020). To encourage active online learning in terms of teaching presence, the teacher should create instances in which the students will be solving their problems (Dunlap \& Lowenthal, 2018).

\subsection{Theoretical Framework}

This study used Garrison's CoI (Community of Inquiry) model as its theoretical foundation. The CoI framework for e-learning environments created by Garrison, Anderson \& Archer (2000) presents a collaborative-constructivist position in analyzing the properties of an online learning experience. It provides a comprehensive theoretical model that can illuminate both online learning research and online teaching practice. It asserts that effective online learning happens by creating a community that promotes notable inquiry and profound 
learning (Rovai, 2002; Thompson \& MacDonald, 2005; Shea, 2006). As such is not a minor challenge in the online learning environment.

Figure 2.

The Community of Inquiry Framework

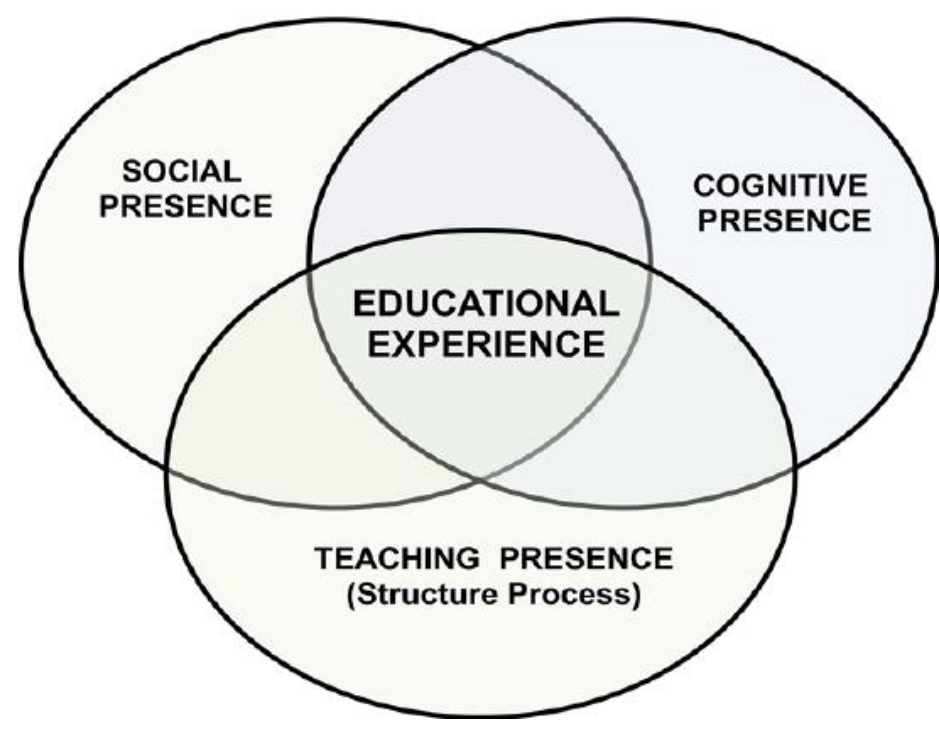

The CoI model comprises cognitive presence, social presence, and teaching presence as shown below in Figure 1. At the core of the overlap of these components was a profound and meaningful educational experience. The objective of this model is to determine, explain, and assess the components of a collaborative and valuable learning experience (Garrison, Anderson, \& Archer, 2010). As CoI contends, learning experience is defined by how cognitive presence, social presence, and teaching presence extend over and work adjacent to each other. This model supports online learning as active learning environments reliant on the collaboration of educators and learners. The "presence" is a social aspect and exhibits itself through interplays among educators and learners. This model has become well-known for online learning that is highly interactive among educators and learners using videoconferencing, wikis, blogs, and discussion boards (Picciano, 2017). For a better comprehension of these interactions, it is crucial to have a close examination of each of the presences that the model is composed of. Significant effort has been exerted on examining each of the three presences within the Col framework. These three elements have been confirmed to be relatively well-built. Still, there have been refinements. After publishing 
articles about the framework, the center and vocabulary changed to a more comprehensive perspective of online learning (Garrison, Anderson, \& Archer, 2010).

\section{Methodology}

\subsection{Research Design}

This study employed quantitative research as it summarizes results numerically while descriptive survey research was adopted as the primary approach in examining the data. Descriptive-survey research as described by Lodico, et al. (2006), intends to report behaviors and collate people's discernment, beliefs, perspectives, and views regarding a prevailing issue in education. These reports are organized by stating the number of persons in each response.

A survey or questionnaire is the principal instrument utilized to collect information in descriptive-survey research. Specifically, a one-shot survey design was adopted. In using this approach, questionnaires are sent to respondents at one particular period of time to collect their perceptions about a present problem or issue. Common responses to the questionnaire are quantitative and were collated quantitatively. The sample is chosen from the population to enable its conclusions to infer broader applicability (Lodico, et al., 2006). Analyzing the learning environment with the treatment of quantitative perceptual instruments is more beneficial than other types of evaluation (Fraser \& Fisher, 1994; Fraser \& Walberg, 1995). Some of its advantages include, but are not limited to being more cost-effective, experiential, has combined observations, determinants of student behaviors, and consider more differences in student learning.

\subsection{Participants and Data Gathering}

The study was conducted at Laguna State Polytechnic University-San Pablo City Campus (LSPU-SPCC). The questionnaire was administered among the fourth-year students enlisted under the College of Teacher Education during the 1st semester of Academic Year 2021 - 2022 with the courses Bachelor of Science in Secondary Education (BSED), Bachelor of Elementary Education (BEED), Bachelor of Physical Education (BPED), Bachelor of Technology and Livelihood Education (BTLED, and Bachelor of Technical Vocational 
Teacher Education (BTVTED). These students are taking their field study in the 1st semester and internship in the 2nd semester.

The questionnaire was encoded to Google forms and e-mailed to respondents' institutional email accounts. All fourth-year students in the College of Teacher Education were targeted as respondents but due to poor internet connections in some locations, only 106 students or $39.7 \%$ of the population were retrieved. The responses were downloaded as CSV file and converted to Microsoft Excel file for further statistical analysis.

The BSED has the most number of respondents with 125 students followed by 50 BPED, 49 BTVTED, 40 BEED, and 11 BTLED students.

\subsection{Research Instrument}

The questionnaire is the primary instrument used to obtain data in a one-shot survey design. The survey was administered within a month from September to October 2021. The questionnaire is divided into three sections. The first section collects the demographic information of the respondents including age, sex, year level, course, and latest general weighted average (GWA). The second section is a modified 35-item Online Learning Environment Survey (OLLES) that gathers the perception of the respondents on their online learning environment. The last section is the Community of Inquiry (CoI) survey that accumulates the perception of the learners regarding their educational experiences by exploring the interplay of the three presences.

At the end of the $20^{\text {th }}$ century and the beginning of the $21^{\text {st }}$ century, there has been a concentration on creating instruments that measure the learning environments in online education (Clayton, 2007). The OLLES captures the learners' perception of the e-learning environment. The modified 35-item OLLES comprise the seven (7) scales recognized as Student Collaboration (SC), Computer Competence (CC) Active Learning (AL), Teacher Support (TS), Information Design and Appeal (ID), Material Environment (ME), and Reflective Thinking (RT). Each scales contain five (5) items in the instrument. These scales are described as follows:

1. Computer Competence (CC). The extent to which the learner feels satisfied and convenient in operating computers in the e-learning environment. On this scale, the 
perception of learners on their ability to work on their computers as a means to communicate with others and obtain information is investigated.

2. Material Environment (ME). The extent to which the computer hardware and software are adaptable and easily operated.

3. Student Collaboration (SC). The extent to which learners operate unitedly, know, help, support, and are cooperative with each other. On this scale, the perception of learners on their opportunities to cooperate, exchange information, and engage in collaboration is examined.

4. Teacher Support (TS). The extent to which the teacher facilitates learners in their learning and presents delicate, continuing, and reassuring support. On this scale, the perception of the learners on the guidance, confidence, and assistance offered by the teacher is reviewed.

5. Active Learning (AL). The extent to which the computer exercises assist learners in their learning and provide continuing and appropriate feedback.

6. Information Design and Appeal (ID). The extent to which course materials are clear, engaging and presentable to the student.

7. Reflective Thinking (RT). The extent to which reflective activities are supported and how students appreciated learning and engaging in the e-learning environment.

The internal consistency of OLLES, as affirmed by Cronbach Alpha coefficients in the validation conducted by Clayton (2007), all above 0.75 , is considered acceptable. He asserted that the instrument was valid and reliable to explore techniques that enhance the online learning environment.

The last section of the questionnaire is the CoI Survey. It is designed and validated by Arbaugh, et al. (2008). The CoI framework observes the online learning experience because of the interrelations of social, teaching, and cognitive presence. The three presences are described as follows:

1. Social presence. The extent to which learners feel socially and emotionally associated with others in an e-learning environment. 
2. Teaching presence. The plan, implementation, and control of cognitive and social methods for the achievement of individually meaningful and educationally valuable learning outcomes.

3. Cognitive presence. The degree to which learners can create and verify meaning through supported reflection and discussion.

The CoI survey presents a reliable tool for the occurrence of a community of inquiry that measures the social, teaching, and cognitive presence in online learning environments. It is an instrument consisting of consensual and statistically validated items that operationalize the notions in the CoI model. This may be adopted for the continued clarification of ideas in the framework. It may also be utilized for useful applications or to assess an online community of inquiry once implemented (Arbaugh, et al., 2008).

\section{Findings and Discussion}

\section{Table 1}

Students' Perception on Online Education In Terms Of Collaboration

\begin{tabular}{llccc}
\hline & \multicolumn{1}{c}{ Indicator } & Mean & SD & Interpretation \\
\hline 1 & I communicate regularly with other students in this course. & 3.84 & 1.08 & Often \\
2 & I often ask other students for help in activities we are doing. & 3.51 & 1.08 & Often \\
3 & Other students provide feedback on activities I have done. & 3.27 & 1.07 & Sometimes \\
4 & I share resources and information with other students. & 3.92 & 1.02 & Often \\
5 & Other students share resources and information with me. & 3.70 & 1.05 & Often \\
\hline & Over-all mean & $\mathbf{3 . 6 5}$ & $\mathbf{1 . 0 6}$ & Often \\
\hline
\end{tabular}

Legend: 4.50-5.0 - always, 3.50-4.49 - often, 2.50-3.49 - sometimes, 1.50-2.49 - seldom, 1.0-1.49 - never

It is shown in Table 1 that indicator 4 has the highest mean $(M=3.92, S D=1.02)$, interpreted as "often". Indicator 3 has the lowest mean $(\mathrm{M}=3.27, \mathrm{SD}=1.07)$, interpreted as "sometimes". Generally, the respondents perceived collaboration in an online learning environment as "often" $(\mathrm{M}=3.65, \mathrm{SD}=1.06)$.

Based from the results, learners often use personal and class communication devices in their online courses. Learners converse favorably with other learners in the course and acknowledge other learners who constantly communicate with them. This communication 
happens to dispense information and resources. Learners ask their classmates for help in achieving particular tasks. They are moderately willing to give feedback to other students regarding activities undertaken. The results also indicate that learners work unitedly to help and support each other and are often cooperative. They recognized the chances to cooperate, exchange information, and engage in collaboration. Accordingly, Haythornthwaite (2006) expanded the extent of collaboration from learning about content to a broader context of confidence in groups, the growth of an online knowledge community, and the elevation of collaborative practices. Since collaboration can intend many things, educators are prompted to examine the kind of collaboration they are designing and plan accordingly, considering the facilities and difficulties of the online learning environment.

Table 2

Students' Perception on Online Education In Terms Of Computer Competence

\begin{tabular}{llccc}
\hline \multicolumn{1}{c}{ Indicator } & Mean & SD & Interpretation \\
\hline 1 & I am confident and competent using a computer. & 3.77 & .939 & Often \\
2 & $\begin{array}{l}\text { I am confident in using the World Wide Web to search for } \\
\text { information. }\end{array}$ & 3.91 & .879 & Often \\
3 & I am able to reconnect to the network if anything goes wrong. & 3.86 & .930 & Often \\
4 & If necessary, I can select and print documents from the Internet. & 3.71 & 1.12 & Often \\
5 & $\begin{array}{l}\text { If necessary, I can electronically store information on my } \\
\text { computer or disk. }\end{array}$ & 3.82 & 1.07 & Often \\
\hline & Over-all mean & $\mathbf{3 . 8 1}$ & $\mathbf{0 . 9 8 7}$ & Often \\
\hline
\end{tabular}

Legend: 4.50-5.0 - always, 3.50-4.49 - often, 2.50-3.49 - sometimes, 1.50-2.49 - seldom, 1.0-1.49 - never

Table 2 reflects that indicator 2 has the highest mean $(\mathrm{M}=3.91, \mathrm{SD}=.879)$, which is interpreted as "often." Indicator 4 has the lowest mean $(\mathrm{M}=3.71, \mathrm{SD}=1.12)$ equivalent to "often". Overall, the respondents perceived computer competence in an online learning environment as "often" $(\mathrm{M}=3.81, \mathrm{SD}=0.987)$.

The result shows that learners perceived they were technologically capable of engaging sufficiently in the online learning environment. They were positive and skilled in using computers, and in searching, recovering, saving, and managing information from the web. It is evident from the result that learners utilize computers to communicate with others and to obtain information. They feel satisfied and appreciate the use of computers in the online learning environment. Learners perceived they can operate their computers conveniently in the e-learning environment. 
The study of Meiselwitz and Trajkovski (2006) noted that expertise and skills similar to simple electronic communication and basic internet knowledge are adequate to improve a user's view of higher system usability and higher learning outcomes. Similarly, students do not need advanced computer competence or knowledge about web applications to increase regard of high system usability or high learning outcomes.

\section{Table 3}

Students' Perception on Online Education In Terms Of Active Learning

\begin{tabular}{|c|c|c|c|c|}
\hline & Indicator & Mean & SD & Interpretation \\
\hline 1 & The feedback I receive from activities / quizzes is meaningful. & 4.10 & 1.05 & Often \\
\hline 2 & $\begin{array}{l}\text { The feedback from activities / quizzes helps me to locate where } \\
\text { I am having difficulties. }\end{array}$ & 4.11 & 1.04 & Often \\
\hline 3 & $\begin{array}{l}\text { I am motivated by the responses I get from the activities / } \\
\text { quizzes included in this course. }\end{array}$ & 3.99 & 1.05 & Often \\
\hline 4 & $\begin{array}{l}\text { The activities / quizzes provided in the course enhance my } \\
\text { learning. }\end{array}$ & 4.12 & 1.04 & Often \\
\hline 5 & $\begin{array}{l}\text { The responses to the activities help me understand where I am } \\
\text { having difficulty. }\end{array}$ & 4.08 & 1.01 & Often \\
\hline & Over-all mean & 4.08 & 1.03 & Often \\
\hline
\end{tabular}

It is exhibited in Table 3 that indicator 4 has the highest mean $(M=4.12, S D=1.04)$ while indicator 3 has the lowest mean $(\mathrm{M}=3.99, \mathrm{SD}=1.05)$ which are both interpreted as "often". The general perception of the respondents on the active learning in an online learning environment was “often” $(\mathrm{M}=4.08, \mathrm{SD}=1.03)$.

The result implies that learners acknowledge the significance of feedback formed in an online learning environment. Feedbacks prompted them to ponder on learning activities and increase their comprehension of the materials presented. It is reflected in the result that the online learning environment supports learners in education and renders proper feedback. Accordingly, Cummings, et al. (2017) suggested that learners must be involved in active learning opportunities to make them feel associated with the class and not just inactive observers. Active learning requires educators to be more student-centered in the methods of teaching and learning that they employ. More than ever, both in K-12 and higher education, active learning strategies are appropriated to equip digital-age students. 
Table 4

Students' Perception on Online Education In Terms Of Teacher Support

\begin{tabular}{llccc}
\hline \multicolumn{1}{c}{ Indicator } & Mean & SD & Interpretation \\
\hline 1 & The teacher encourages my participation. & 3.93 & .979 & Often \\
2 & The teacher responds promptly to my queries. & 3.92 & .947 & Often \\
3 & The feedback I receive from my teacher helps me identify the & 4.11 & .929 & Often \\
& things I do not understand. & 3.99 & .845 & Often \\
4 & The teacher addresses group queries promptly & 4.11 & .876 & Often \\
5 & The teacher participates regularly in group discussions. & $\mathbf{4 . 0 1}$ & $\mathbf{0 . 9 2}$ & Often \\
\hline & \multicolumn{1}{c}{ Over-all mean }
\end{tabular}

Legend: 4.50-5.0 - always, 3.50-4.49 - often, 2.50-3.49 - sometimes, 1.50-2.49 - seldom, 1.0-1.49 - never

It is displayed in Table 4 that indicator 3 and 5 has the highest mean $(M=4.11$, $\mathrm{SD}=.929)$ and $(\mathrm{M}=4.11, \mathrm{SD}=.876)$ respectively as it is interpreted as "often". Indicator 2 has the lowest mean $(\mathrm{M}=3.92, \mathrm{SD}=.947)$ as it is interpreted as "often". Collectively, the respondents perceived teacher support in an online learning environment as "often" $(\mathrm{M}=4.01$, $\mathrm{SD}=0.92)$.

The result implies that learners are satisfied with teacher communication in the course. They feel that the teacher actively supports group and individual participation and gives adequate guidance in the conduct of the course. Educators provide proper feedback to learners and are usually active participants and co-learners. It can be asserted based on the result that the teacher helps, befriends, trusts, and is interested in the students. The teacher facilitates students in their learning and renders responsive, continuous, and reassuring support. Learners appreciate the guidance, confidence, and support offered by the teacher.

McPherson and Nunes (2004) discussed the significance of online teachers in the achievement of online learning. Online educators perform a vital role in e-learning since they are facilitators who are mainly in charge of the instruction and learners' support. They concluded that educators must possess a relevant set of skills and attributes aside from mastery of the subject matter.

It is summarized in Table 5 that indicator 4 has the highest mean $(\mathrm{M}=4.17, \mathrm{SD}=.867)$ as it is interpreted as "often". Indicator 2 has the lowest mean $(\mathrm{M}=4.02, \mathrm{SD}=.905)$ as it is interpreted as "often". Overall, the respondents perceived information design and appeal in an online learning environment as "often" $(\mathrm{M}=4.07, \mathrm{SD}=0.89)$. 
Table 5

Students' Perception on Online Education In Terms Of Information Design and Appeal

\begin{tabular}{lllll}
\hline \multicolumn{1}{c}{ Indicator } & Mean & SD & Interpretation \\
\hline 1 & $\begin{array}{l}\text { The choice of colours and style used in the text assisted my } \\
\text { being able to read clearly. }\end{array}$ & 4.03 & .889 & Often \\
2 & $\begin{array}{l}\text { The backgrounds used in tables and pages enhance the look of } \\
\text { the material. }\end{array}$ & 4.02 & .905 & Often \\
3 & $\begin{array}{l}\text { The material shows originality and creativity in the layout. } \\
4\end{array} \quad 4.05$ & .888 & Often \\
$\quad \begin{array}{l}\text { I find the graphics (photos, images and graphs) used are } \\
\text { appropriate to the text and helps me understand. }\end{array}$ & 4.17 & .867 & Often \\
$\quad \begin{array}{l}\text { I find the graphics (photos, images and graphs) used are well } \\
\text { designed and visually appealing. }\end{array}$ & 4.08 & .912 & Often \\
\hline Over-all mean & $\mathbf{4 . 0 7}$ & $\mathbf{0 . 8 9}$ & Often \\
\hline
\end{tabular}

Legend: 4.50-5.0 - always, 3.50-4.49 - often, 2.50-3.49 - sometimes, 1.50-2.49 - seldom, 1.0-1.49 - never

The results reflected that learners considered the digital material displayed in the course was visually desirable. The color, style, and font for text and backgrounds assisted students in reading the material as it reduced screen glare and eye strain. The graphics applied in the course were recognized and helped students' comprehension. The result affirmed that the class materials used in their online learning are enjoyable and visually captivating. It designates that course materials are comprehensive, engaging, and presentable to the learners.

Clayton (2007) asserted that, in preparing digital materials, teachers should develop attractive materials for ease of study and grasp. These materials will involve learners, deepen their knowledge, and increase their fulfillment and accomplishment.

\section{Table 6}

Students' Perception on Online Education In Terms Of Material Environment

\begin{tabular}{|c|c|c|c|c|}
\hline & Indicator & Mean & SD & Interpretation \\
\hline 1 & $\begin{array}{l}\text { The instructions provided to use the tools within the site are } \\
\text { clear and precise. }\end{array}$ & 3.94 & .944 & Often \\
\hline 2 & $\begin{array}{l}\text { The software I use is suitable for participating fully in the } \\
\text { course. }\end{array}$ & 4.01 & .990 & Often \\
\hline 3 & $\begin{array}{l}\text { I am able to install the appropriate software needed to } \\
\text { participate in this course with ease. }\end{array}$ & 3.87 & .906 & Often \\
\hline 4 & $\begin{array}{l}\text { All software applications needed to participate in this course } \\
\text { are provided. }\end{array}$ & 3.94 & 1.01 & Often \\
\hline 5 & $\begin{array}{l}\text { There is little delay in opening and using the software } \\
\text { applications used in this course. }\end{array}$ & 3.67 & .953 & Often \\
\hline & Over-all mean & 3.89 & 0.96 & Often \\
\hline
\end{tabular}


It is indicated in Table 6 that indicator 2 has the highest mean $(\mathrm{M}=4.01, \mathrm{SD}=.990)$ as it is interpreted as "often". Indicator 5 has the lowest mean $(\mathrm{M}=3.67, \mathrm{SD}=.953)$ as it is interpreted as "often". Overall, the respondents perceived the material environment in an online learning environment as “often” $(\mathrm{M}=3.89, \mathrm{SD}=0.96)$.

The result displays that learners considered they were in charge of their online learning environment. They obtained relevant support files to use software applications needed in the course. Learners have downloaded the proper software applications and installed them with minimal problems. The software applications did not create unnecessary loading on their computer processor. Learners have completed online learning activities with limited technical difficulties. It can be inferred from the result that the computer hardware and software are flexible and easily commanded. It reflects the adequacy and userfriendliness of the computer hardware and software.

For Clayton (2007), teachers need to create a course with low computer usage applications whenever possible. It will guarantee that learners will not be discouraged by low response times from their computers.

\section{Table 7}

Students' Perception on Online Education In Terms Of Reflective Thinking

\begin{tabular}{|c|c|c|c|c|}
\hline & Indicator & Mean & SD & Interpretation \\
\hline 1 & I find using the Internet for learning is stimulating. & 3.82 & .984 & Often \\
\hline 2 & $\begin{array}{l}\text { I have no problems accessing and going through the materials } \\
\text { on my own. }\end{array}$ & 3.56 & .895 & Often \\
\hline 3 & $\begin{array}{l}\text { I feel I am in control of my learning as I review the material } \\
\text { provided. }\end{array}$ & 3.75 & .874 & Often \\
\hline 4 & $\begin{array}{l}\text { I feel the web based learning approach can substitute for, or } \\
\text { enhance the normal classroom approach. }\end{array}$ & 3.56 & .977 & Often \\
\hline 5 & I feel I learn more in the online environment. & 3.20 & .055 & Often \\
\hline & Over-all mean & 3.58 & 0.96 & Often \\
\hline
\end{tabular}

Legend: 4.50-5.0 - always, 3.50-4.49 - often, 2.50-3.49 - sometimes, 1.50-2.49 - seldom, 1.0-1.49 - never

It is detailed in Table 7 that indicator 1 has the highest mean $(\mathrm{M}=3.82, \mathrm{SD}=.984)$ as it is interpreted as "often". Indicator 5 has the lowest mean $(\mathrm{M}=3.20, \mathrm{SD}=.055)$ as it is interpreted as "often". In a general sense, the respondents perceived reflective thinking in an online learning environment as "often" $(\mathrm{M}=3.58, \mathrm{SD}=0.96)$. 
The result exhibits that learners appreciated using computers and the internet for education. They liked using the internet to obtain knowledge and were incited and driven by their online course. Even though they were content with online learning, they still acknowledged the advantages of traditional learning modalities. The result shows that reflective activities are supported. Learners enjoyed studying and cooperating in the elearning environment.

In the study of Levin, He, \& Robbins (2006), they concluded that learners reflected critically on the interplay of classroom management and instruction and realized that online discussions are operational tools for fostering crucial reflection about matters concerning classroom administration. Learners are satisfied with and can acquire knowledge in synchronous classes. However, adult learners should be given choices in discussion formats so they can engage in critical reflection.

\section{Table 8}

Students' Perception on Educational Experience In Terms Of Social Presence

\begin{tabular}{llccc}
\hline \multicolumn{1}{c}{ Indicator } & Mean & SD & Interpretation \\
\hline 1 & $\begin{array}{l}\text { Getting to know other course participants gave me a sense of } \\
\text { belonging in the course. }\end{array}$ & 3.95 & .809 & Agree \\
2 & & & Agree \\
& $\begin{array}{l}\text { I was able to form distinct impressions of some course } \\
\text { participants. }\end{array}$ & 3.90 & .716 & Agree \\
3 & $\begin{array}{l}\text { Online or web-based communication is an excellent medium } \\
\text { for social interaction. }\end{array}$ & 3.71 & .850 & Agree \\
4 & I felt comfortable conversing through the online medium. & 3.70 & .938 & Agree \\
\hline I felt comfortable participating in the course discussions. & 3.75 & .937 & Agree \\
\hline & Over-all mean & $\mathbf{3 . 8 0}$ & $\mathbf{0 . 8 5}$ &
\end{tabular}

Legend: 4.5-5.0 - strongly agree, 3.50-4.49 - agree, 2.50-3.49 - neutral, 1.50-2.49 - disagree, 1.0-1.49 strongly disagree

It is presented in Table 8 that indicator 1 has the highest mean $(\mathrm{M}=3.95, \mathrm{SD}=.809)$ as it is interpreted as "agree". Indicator 4 has the lowest mean $(\mathrm{M}=3.70, \mathrm{SD}=.938)$ as it is interpreted as "agree". On average, the respondents perceived social presence in their learning experience as "agree" $(\mathrm{M}=3.80, \mathrm{SD}=0.85)$.

Kear (2010) asserted that social presence illuminates aspects of online communication for learning. Communication environment and learner's behavior impact social presence. Furthermore, learning environments can influence how people act towards 
one another. To increase social presence, communication systems for learning should be well-designed and used excellently.

As the results revealed, the learners can socially and emotionally relate with others in an online learning environment.

Table 9

Students' Perception on Educational Experience In Terms Of Teaching Presence

\begin{tabular}{llllc}
\hline \multicolumn{1}{c}{ Indicator } & Mean & SD & Interpretation \\
\hline 1 & The instructor clearly communicated important course topics. & 4.24 & .724 & Agree \\
2 & $\begin{array}{l}\text { The instructor clearly communicated important course goals. } \\
3\end{array}$ & 4.25 & .744 & Agree \\
$\begin{array}{l}\text { The instructor provided clear instructions on how to participate } \\
\text { in course learning activities. }\end{array}$ & 4.22 & .756 & Agree \\
4 & $\begin{array}{l}\text { The instructor clearly communicated important due dates/time } \\
\text { frames for learning activities. }\end{array}$ & 4.25 & .769 & Agree \\
5 & $\begin{array}{l}\text { The instructor was helpful in identifying areas of agreement } \\
\text { and disagreement on course topics that helped me to learn. }\end{array}$ & 4.21 & .700 & Agree \\
\hline Over-all mean & $\mathbf{4 . 2 3}$ & $\mathbf{0 . 7 4}$ & Agree \\
\hline
\end{tabular}

Legend: 4.5-5.0 - strongly agree, 3.50-4.49 - agree, 2.50-3.49 - neutral, 1.50-2.49 - disagree, 1.0-1.49 strongly disagree

It is shown in Table 9 that indicator 2 and indicator 4 have the highest mean $(M=4.25$, $\mathrm{SD}=.744)$ and $(\mathrm{M}=4.25, \mathrm{SD}=769)$ respectively, as these are interpreted as "agree". Indicator 5 has the lowest mean $(\mathrm{M}=4.21, \mathrm{SD}=.700)$ as it is interpreted as "agree". Overall, the respondents perceived teaching presence in their learning experience as "agree" $(\mathrm{M}=4.23$, $\mathrm{SD}=0.74)$.

Teaching presence is the plan, implementation, and management of cognitive and social processes to actualize meaningful and educationally valuable learning outcomes (Anderson, Rourke, Garrison \& Archer, 2001).

The study of Gurley (2018) asserts that educators who participated in prescribed training programs, like certification programs, are more positive in their capabilities to facilitate student learning in blended and online courses. Faculty development and mentoring programs capacitate educators to have appropriate teaching pedagogies and teaching presence behaviors, particularly in online learning environments.

As reflected on the gathered data, the design, execution, and control of cognitive and social presences to achieve individually meaningful and educationally valuable learning outcomes duly are observed. 
Table 10

Students' Perception on Educational Experience In Terms Of Cognitive Presence

\begin{tabular}{llccc}
\hline \multicolumn{1}{c}{ Indicator } & Mean & SD & Interpretation \\
\hline 1 & Problems posed increased my interest in course issues. & 3.77 & .820 & Agree \\
2 & Course activities piqued my curiosity. & 3.82 & .802 & Agree \\
3 & I felt motivated to explore content related questions. & 3.92 & .765 & Agree \\
4 & $\begin{array}{l}\text { I utilized a variety of information sources to explore problems } \\
\text { posed in this course. }\end{array}$ & 3.97 & .798 & Agree \\
5 & $\begin{array}{l}\text { Brainstorming and finding relevant information helped me } \\
\text { resolve content related questions. }\end{array}$ & 4.06 & .860 & Agree \\
\hline & Over-all mean & $\mathbf{3 . 9 1}$ & $\mathbf{0 . 8 1}$ & Agree \\
\hline $\begin{array}{l}\text { Legend: 4.5-5.0 - strongly agree, 3.50-4.49 - agree, 2.50-3.49-neutral, 1.50-2.49- disagree, 1.0-1.49- } \\
\text { strongly disagree }\end{array}$ & & &
\end{tabular}

It is exhibited in Table 10 that indicator 5 has the highest mean $(\mathrm{M}=4.06, \mathrm{SD}=.860)$ as it is interpreted as "agree". Indicator 1 has the lowest mean $(\mathrm{M}=3.77, \mathrm{SD}=.820)$ as it is interpreted as "agree". In general terms, the respondents perceived social presence in their learning experience as "agree" $(\mathrm{M}=3.91, \mathrm{SD}=0.81)$.

Kilis \& Y1ldırım (2019) prescribed creating activities that apply to real-life and providing situations for these activities instead of purely factual knowledge. They also recommended a problem-based learning approach in devising activities to improve students' reflections and critical thinking. It will assist them in inventing new knowledge or in deepening their existing consciousness.

As indicated on the gathered data, learners can construct and validate meaning using supported reflection and discussion.

\section{Table 11}

Significant Relationship Between The Perception Of The Respondents On Online Education As An Active Learning Environment And Perception Of The Respondents On The Social Presence

\begin{tabular}{lccc} 
& $\begin{array}{c}\text { Social Presence } \\
\text { r-value }\end{array}$ & p-value & Interpretation \\
\hline Student Collaboration & $.397^{* *}$ & .000 & Significant \\
Computer Competence & $.354^{* *}$ & .000 & Significant \\
Active Learning & $.684^{* *}$ & .000 & Significant \\
Teacher Support & $.403^{* *}$ & .000 & Significant \\
Information Design and Appeal & $.480^{* *}$ & .000 & Significant \\
Material Environment & $.517^{* *}$ & .000 & Significant \\
Reflective Thinking & $.588^{* *}$ & .000 & Significant \\
\hline
\end{tabular}

Legend: ** Correlation is significant at the 0.01 level (2-tailed). 
It is presented in Table 11 that Active Learning has the highest r-value (r-value $=.684$, $\mathrm{p}$-value $=.000)$ as it is interpreted as "significant". Computer competence has the lowest $\mathrm{r}$ value $(\mathrm{r}$-value $=.354, \mathrm{p}$-value $=.000)$ as it is interpreted as "significant". Generally, there is a significant relationship between online learning environment and social presence. It implies that Student Collaboration, Computer Competence, Active Learning, Teacher Support, Information Design and Appeal, Material Environment, and Reflective Thinking has a significant correlation with Social Presence separately and collectively.

\section{Table 12}

Significant Relationship Between The Perception Of The Respondents On Online Education As An Active Learning Environment And Perception Of The Respondents On The Teaching Presence

\begin{tabular}{lccc}
\hline & $\begin{array}{c}\text { Teaching } \\
\text { Presence } \\
\text { r-value }\end{array}$ & $\begin{array}{c}\text { p-value } \\
\text { Interpretation }\end{array}$ & Significant \\
\hline Student Collaboration & $.409^{* *}$ & .000 & Significant \\
Computer Competence & $.317^{* *}$ & .001 & Significant \\
Active Learning & $.457^{* *}$ & .000 & Significant \\
Teacher Support & $.588^{* *}$ & .000 & Significant \\
Information Design and Appeal & $.469^{* *}$ & .000 & Significant \\
Material Environment & $.492^{* *}$ & .000 & Significant \\
Reflective Thinking & $.451^{* *}$ & .000 & \\
\hline
\end{tabular}

Legend: $* *$ Correlation is significant at the 0.01 level (2-tailed).

It is presented in Table 12 that Teacher Support has the highest $r$-value ( $r$-value $=.588$, $\mathrm{p}$-value $=.000)$ as it is interpreted as "significant". Computer competence has the lowest $\mathrm{r}$ value $(\mathrm{r}$-value $=.317$, $\mathrm{p}$-value $=.001)$ as it is interpreted as "significant". Collectively, there is a significant relationship between online learning environment and teaching presence. It signifies that Student Collaboration, Computer Competence, Active Learning, Teacher Support, Information Design and Appeal, Material Environment, and Reflective Thinking significantly correlate with Teaching Presence individually and accumulatively.

It is presented in Table 13 that Reflective Thinking has the highest r-value ( $r$ value $=.720$, $\mathrm{p}$-value $=.000$ ) as it is interpreted as "significant". Computer Competence and Student Collaboration has the lowest $r$-value $(r$-value $=.545, \mathrm{p}$-value $=.000)$ as it is interpreted as "significant". Overall, there is a significant relationship between online learning 
environment and cognitive presence. It denotes that Student Collaboration, Computer Competence, Active Learning, Teacher Support, Information Design and Appeal, Material Environment, and Reflective Thinking significantly correlate with Cognitive Presence independently and as a whole.

\section{Table 13}

Significant Relationship Between The Perception Of The Respondents On Online Education As An Active Learning Environment And Perception Of The Respondents On The Cognitive Presence

\begin{tabular}{lccc} 
& $\begin{array}{c}\text { Cognitive } \\
\text { Presence } \\
\text { r-value }\end{array}$ & p-value & Interpretation \\
\hline Student Collaboration & $.545^{* *}$ & .000 & Significant \\
Computer Competence & $.545^{* *}$ & .000 & Significant \\
Active Learning & $.628^{* *}$ & .000 & Significant \\
Teacher Support & $.592^{* *}$ & .000 & Significant \\
Information Design and Appeal & $.579^{* *}$ & .000 & Significant \\
Material Environment & $.642^{* *}$ & .000 & Significant \\
Reflective Thinking & $.720^{* *}$ & .000 & Significant \\
\hline
\end{tabular}

Legend: ** Correlation is significant at the 0.01 level (2-tailed).

\section{Conclusion}

With the current learning modalities, educational activities are not confined to text, print-based materials, time, or space anymore. Educators are driven to create suitable pedagogies to deal with digital ways of teaching and learning. The results of the study affirmed that learners probed by this study perceived the online learning environment as favorable. It is also duly affirmed by this study that learners view their learning experiences during the new normal as meaningful and collaborative-constructivist. It is therefore necessary to consider the integration of social presence, teaching presence, and cognitive presence to achieve that kind of learning experience.

It is believed the present study is valuable to school administrators, educators, learners, future researchers, and all those concerned with educational policy. Its timeliness and relevance can offer vital contributions to teaching, learning, and research. In reference to delivering a collaborative-constructivist learning experience among learners, the following recommendations are set-forth: 
Educators should include activities that encourage collaboration. These activities will promote a spirit of community and belongingness that may boost student motivation and lessen drop-out. Educators should specify the technical skills needed to engage in the course. It will assure students will not be discouraged from performing tasks that are beyond their technical competency. It will increase a sense of command in their learning environment that will build fulfilment. Educators need to create activities that provide essential feedback to learners, enriching their knowledge, and improving student gratification and accomplishment. Educators should frequently communicate with their students and offer precise feedback when needed. These may help increase student participation and success. Educators should ensure communication activities to imbibe a sense of belongingness and community. It conceivably enhances student well-being.

Finally, several significant limitations should be a concern. First, a small sample of learners served as the respondents of this study. Further studies about the matter may also be conducted using a combination of quantitative approach and qualitative approach. Lastly, future researchers may also explore other areas affected by learners' online learning environment.

\section{References}

Anderson, T.; Rourke, L.; Garrison, D.R.; Archer, W. (2001). Assessing Teaching Presence in a Computer Conferencing Context. J. Asynchronous Netw. 5, 1-17. http://citeseerx.ist.psu.edu/viewdoc/download?doi=10.1.1.409.9114\&rep=rep1\&type $=$ pdf

Arbaugh, B., Cleveland-Innes, M., Diaz, S., Garrison, D., Ice, P., Richardson, J., Shea, P. \& Swan, K. (2008). Community of Inquiry Survey. https://coi.athabascau.ca/coimodel/coi-survey/

Arbaugh, B., Cleveland-Innes, M., Garrison, D., Ice, P., Richardson, J., Swan, K. (2008). Validating a Measurement Tool of Presence in Online Communities of Inquiry. https://www.researchgate.net/publication/265406073_Validating_a_Measurement_T ool_of_Presence_in_Online_Communities_of_Inquiry

Bates, T. (2000). Distance education in dual mode higher education institutions: Challenges and changes. University of British Columbia, Continuing Studies: Distance Education \& Technology: http://bates.cstudies.ubc.ca/

Callo, E. \& Yazon, A. (2020). Exploring the Factors Influencing the Readiness of Faculty and Students on Online Teaching and Learning as an Alternative Delivery Mode for 
the New Normal. Universal Journal of Educational Research, 8(8), 3509 - 3518. DOI: 10.13189/ujer.2020.080826.

Chang, V., \& Fisher, D. (1999). Students' perceptions of the efficacy of Web- based learning environment: The emergence of a new learning instrument. Paper presented at the HERDSA Annual International Conference, Melbourne.

Chang, V., \& Fisher, D. (2001). The validation and application of a new learning environment instrument to evaluate online learning in higher education. Paper presented at the Australian Association for Research in Education, Fremantle.

Charlotte N. Gunawardena \& Frank J. Zittle (1997) Social presence as a predictor of satisfaction within a computer-mediated conferencing environment, American Journal of Distance Education, 11:3, 8-26, DOI: 10.1080/08923649709526970

CHED. (2020). CHED COVID-19 ADVISORY NO. 3. https://ched.gov.ph/wpcontent/uploads/CHED-COVID-2019- Advisory-No.-3.pdf

Clayton, J. (2007). Development and Validation of an Instrument for Assessing Online Learning Environments in Tertiary Education: The Online Learning Environment Survey (OLLES). Curtin University of Technology, Science and Mathematics Education Centre. http://hdl.handle.net/20.500.11937/550

Clayton, J. (2007). Validation of the online learning environment survey. In ICT: Providing choices for learners and learning. Proceedings ascilite Singapore 2007. https://www.ascilite.org/conferences/singapore07/procs/clayton.pdf

Cooper, V. A., Forino, G., Kanjanabootra, S., \& von Meding, J. (2020). Leveraging the community of inquiry framework to support web-based simulations in disaster studies. The Internet and Higher Education, 47, 100757.

Cummings, C., Mason, D., Shelton, K., \& Baur, K. (2017). Active learning strategies for online and blended learning environments. In Flipped instruction: breakthroughs in research and practice (pp. 88-114). IGI Global.

Czerkawski, B. \& Lyman, E. (2016). An Instructional Design Framework for Fostering Student Engagement in Online Learning Environments. TechTrends. 60. 10.1007/s11528-016-0110-z

Dabbagh, N., \& Bannan-Ritland, B. (2005). Online learning: Concepts, strategies, and application. Upper Saddle River, NJ: Pearson Education, Inc.

DOH. (2021). Department of Health Philippines. https://doh.gov.ph/covid19tracker

Dunlap, J. C. \& Lowenthal, P. R. (2018). Online educators' recommendations for teaching online: Crowdsourcing in action. Open Praxis, 10(1), 79-89. Retrieved from https://openpraxis.org/index.php/OpenPraxis/article/view/721/421

Fraser, B. J., \& Fisher, D. (1994). Assessing and researching the classroom environment. In D. Fisher (Ed.), The Study of Learning Environments (Vol. 8, pp. 23-39). Perth: Curtin University of Technology.

Fraser, B. J., \& Walberg, H. (Eds.). (1995). Improving science education. Chicago: The University of Chicago Press.

Further Education Resources for Learning. (2007). Ferl practitioners' programme. Becta, Further Education Resources for Learning (FERL): http://ferl.becta.org.uk/

Garrison, D. R., Anderson, T., \& Archer, W. (2000). Critical Inquiry in a Text-Based Environment: Computer Conferencing in Higher Education Model. The Internet and Higher Education, 2(2-3), 87-105 Retrieved from 
http://cde.athabascau.ca/coi_site/documents/Garrison_Anderson_Archer_Critical_In quiry_model.pdf

Garrison, D.R.; Anderson, T.; Archer, W. (2010). The first decade of the community of inquiry framework: A retrospective. Internet High. Educ.,13, 5-9. https://doi.org/10.1016/j.iheduc.2009.10.003

Garrison, D.R.; Arbaugh, J.B (2007). Community of inquiry framework: Review, issues, and future directions. Internet High. Educ. 10, 157-172. https://doi.org/10.1016/j.iheduc.2007.04.001

Gurley, L. E. (2018). Educators' Preparation to Teach, Perceived Teaching Presence, and Perceived Teaching Presence Behaviors in Blended and Online Learning $\begin{array}{llll}\text { Environments. } & \text { Online learning, 22(2), }\end{array}$ https://files.eric.ed.gov/fulltext/EJ1181399.pdf

Haynes, D. (2002). The social dimensions of online learning: Perceptions, theories and practical responses. Paper presented at the Distance Education Association of New Zealand, Wellington.

Haythornthwaite, C. (2006). Facilitating collaboration in online learning. Journal of $\begin{array}{llll}\text { Asynchronous } \quad \text { Learning } \quad \text { Networks, } & \text { 10(1), }\end{array}$ http://citeseerx.ist.psu.edu/viewdoc/download?doi=10.1.1.104.2245\&rep=rep1\&type $=$ pdf

Jo IH., Yu T., Lee H., Kim Y. (2015) Relations between Student Online Learning Behavior and Academic Achievement in Higher Education: A Learning Analytics Approach. In: Chen G., Kumar V., Kinshuk, Huang R., Kong S. (eds) Emerging Issues in Smart Learning. Lecture Notes in Educational Technology. Springer, Berlin, Heidelberg. https://doi.org/10.1007/978-3-662-44188-6_38

Kear, Karen (2010). Social presence in online learning communities. In: Proceedings of the 7th International Conference on Networked Learning 2010, 3-4 May 2010, Aalborg, Denmark. https://oro.open.ac.uk/21777/2/299A98F0.pdf

Kent, J., O'Neil, A., \& Page, N. (2006). Improving tertiary teaching: An online approach to professional development. [Electronic version]. In Experience of Learning. Proceedings of the 15th Annual Teaching Learning Forum, 1-2 February 2006. Perth: The University of Western Australia. http://lsn.curtin.edu.au/tlf/tlf2006/refereed/kent.html.

Kilis, S., \& Yıldırım, Z. (2019). Posting patterns of students' social presence, cognitive presence, and teaching presence in online learning. https://open.metu.edu.tr/bitstream/handle/11511/46118/index.pdf

Ladyshewsky, R. (2004). Online learning versus face to face learning: What is the difference? [Electronic version]. Seeking Educational Excellence. Proceedings of the 13th Annual Teaching Learning Forum, 9-10 February 2004. Perth: Murdoch University. http://lsn.curtin.edu.au/tlf/tlf2004/ladyshewsky.html.

Levin, B.B. He, Y., \& Robbins, H.H. (2006). Comparative analysis of preservice teachers' reflective thinking in synchronous vs. asynchronous online case discussions. Journal of Technology and Teacher Education, 14, 439-460. https://libres.uncg.edu/ir/uncg/f/B_Levin_Comparative_2006.pdf

Lodico, M., Spaulding, D., \& Voegtle, K. (2006). Methods in Educational Research. John Wiley \& Sons, Inc. http://stikespanritahusada.ac.id/wpcontent/uploads/2017/04/Marguerite_G._Lodico_Dean_T._Spaulding_KatherinBook Fi.pdf 
Louis-Jean, J., \& Cenat, K. (2020). Beyond the Face-to-Face Learning: A Contextual Analysis. Pedagogical Research, 5(4), em0077. https://doi.org/10.29333/pr/8466

Mann, B. (2000). Internet provision of enrichment opportunities to school and home. [Electronic version]. Australian Educational Computing, 15(1). http://www.acce.edu.au/journal/

Mbati, L.A. (2012). Online learning for social constructivism: creating a conducive environment. Vol. 34, No. 2. https://journals.co.za/doi/pdf/10.10520/EJC130287

McPherson, M. A., \& Nunes, J. M. B. (2004). The role of tutors as an integral part of online learning support. European Journal of Open and Distance Learning.

Meiselwitz, G., \& Trajkovski, G. (2006, June). Effects of computer competency on usability and learning experience in online learning environments. In Seventh ACIS International Conference on Software Engineering, Artificial Intelligence, Networking, and Parallel/Distributed Computing (SNPD'06) (pp. 339-342). IEEE. https://www.researchgate.net/profile/Goran-Trajkovski-

2/publication/4246003_Effects_of_Computer_Competency_on_Usability_and_Learn ing_Experience_in_Online_Learning_Environments/links/570c28b908aee0660351ae 45/Effects-of-Computer-Competency-on-Usability-and-Learning-Experience-inOnline-Learning-Environments.pdf

National Science Board. (2006). Science and engineering indicators 2006 [Electronic version]. Retrieved December 14, 2006, from http://www.nsf.gov/statistics/seind06

Picciano, A. G. (2017). Theories and frameworks for online education: Seeking an integrated model. Online Learning, 21(3), 166-190. doi: 10.24059/olj.v21i3.1225

Quilter-Pinner H and Ambrose A (2020) The 'new normal': The future of education after Covid-19, IPPR. http://www.ippr.org/research/publications/the-new-normal

Radford, A. J. (1997). The Future of Multimedia in Education. First Monday, Volume 2, Number 11 - 3 November 1997. https://www.firstmonday.org/article/view/560/481

Rapanta, C., Botturi, L., Goodyear, P. et al. (2021). Balancing Technology, Pedagogy and the New Normal: Post-pandemic Challenges for Higher Education. Postdigit Sci Educ 3, 715-742. https://doi.org/10.1007/s42438-021-00249-1

Rovai, A.P. (2002). Sense of community, perceived cognitive learning, and persistence in asynchronous learning networks. The Internet and Higher Education, 5(4), 319-332.

Seckman, C. (2018). Impact of interactive video communication versus text-based feedback on teaching, social, and cognitive presence in online learning communities. Nurse Educator, 43(1), 18-22. doi: 10.1097/NNE.0000000000000448

Shea, P.J. (2006). A study of students' sense of learning community in online learning environments. Journal of Asynchronous Learning Networks, 10(1). http://www.sloan- c.org/publications/jaln/v10n1/v10n1_4shea_member.asp

Siragusa, L. (2005). Identification of effective instructional design principles and learning strategies for students studying in Web-based learning environments in higher education. Unpublished Doctor of Philosophy Thesis, Curtin University of Technology, Perth.

Thompson, T.L., MacDonald, C.J. (2005). Community building, emergent design and expecting the unexpected: Creating a quality eLearning experience. The Internet and Higher Education, 8 (3), 233-249. 
Tria, J. Z. (2020). The COVID-19 Pandemic through the Lens of Education in the Philippines: The New Normal. International Journal of Pedagogical Development and Lifelong Learning, 1(1), ep2001. https://doi.org/10.30935/ijpdll/8311

Wood, C. (2005). Highschool.com. Edutopia Magazine, April/May, 32-37.

Worldometer. (2021). COVID-19 Coronavirus Pandemic. Retrieved from https://www.worldometers.info/coronavirus/

Zhu, E., McKnight, R., \& Edwards, N. (2007). Principles of online design. Florida Gulf Coast University, Faculty of Development and Support: http://www.fgcu.edu/onlinedesign/ 